\title{
Florida Springs-A Water-Budget Approach to Estimating Water Availability
}

\author{
Robert L. Knight and Ronald A. Clarke \\ Howard T. Odum Florida Springs Institute, 23695 W. US 27, High Springs, FL 32653, USA
}

\begin{abstract}
Florida's artesian springs receive groundwater outflows from the Floridan Aquifer System and are concentrated north of I-4 and west to the Florida Panhandle. These springs and their resulting spring runs support a unique freshwater ecology dependent on perennial flows, constant temperature and chemistry, and high light transmissivity. Numerous observations indicate that Florida's springs flows are declining as a result of the increasing extraction of groundwater for human uses. North Florida's karst environment is especially susceptible to nitrogen pollution from agricultural and urban development. An empirical springs/aquifer water budget is needed to better understand these spring stressors. Discharge data from 393 of the state's 1,000+ artesian springs are used to estimate trends in total spring discharge by decade since 1930-39. This analysis indicates that average spring flows have declined by about $32 \%$. Large groundwater pumping centers are altering spring flows over the whole springs region. Existing groundwater pumping rates from the Floridan Aquifer in 2010 were more than 30\% of average annual aquifer recharge, and allocated groundwater use in north-central Florida is nearly double current estimated uses. Based on biological research conducted in Florida springs, these flow reductions are from two to six times greater than declines known to result in significant harm to aquatic resources.
\end{abstract}

Key words: Artesian springs, Floridan Aquifer, hydrology, aquatic ecology, aquifer recharge.

\section{Introduction}

North and central Florida contain more than 1,000 artesian springs (springs' region), generally located north of Interstate Highway 4 (approximating a line between Tampa and Orlando; see Fig. 1), and west in Florida's panhandle to Walton County. The primary groundwater source for these springs is the Floridan Aquifer System, a massive limestone/dolomite unit that underlies approximately 100,000 square miles throughout the southeastern U.S. The Floridan Aquifer System underlies southeastern South Carolina, much of the Coastal Plain of Georgia, all of Florida, and extends west into southern Alabama [1]. The limestone/dolomite deposits that make up the Floridan Aquifer System are up to thousands of feet thick in some areas. Porosity and permeability is highly variable both vertically and horizontally in these deposits. Freshwater (defined here as less than 10,000 $\mathrm{mg} / \mathrm{L}$ total dissolved solids concentration) is present in

Corresponding author: Robert L. Knight, Ph.D., director of Florida Springs Institute, research field: aquatic ecosystems. the upper portion of the aquifer system throughout most of the area. In some relatively small areas throughout the southeastern U.S., the entire Floridan Aquifer System contains saltwater (greater than $10,000 \mathrm{mg} / \mathrm{L}$ total dissolved solids concentration) and is not potable. High density saltwater, present in the lower portions of the aquifer system, the Gulf of Mexico, and the Atlantic Ocean, surrounds all of the lower density freshwater in the Floridan Aquifer System. Therefore, saltwater intrusion into the potable water in the Floridan Aquifer System may result from groundwater pumpage in and near coastal areas. Also, there is the potential for vertical up-coning of deep saltwater to wells open to the freshwater portions of the Floridan Aquifer System [2, 3].

All of the freshwater present in the Floridan Aquifer System was originally derived from rainfall that replenishes the groundwater storage through direct and indirect recharge to the system [1]. Natural recharge results only in those areas where the aquifer is not totally confined by low-permeability sediments 


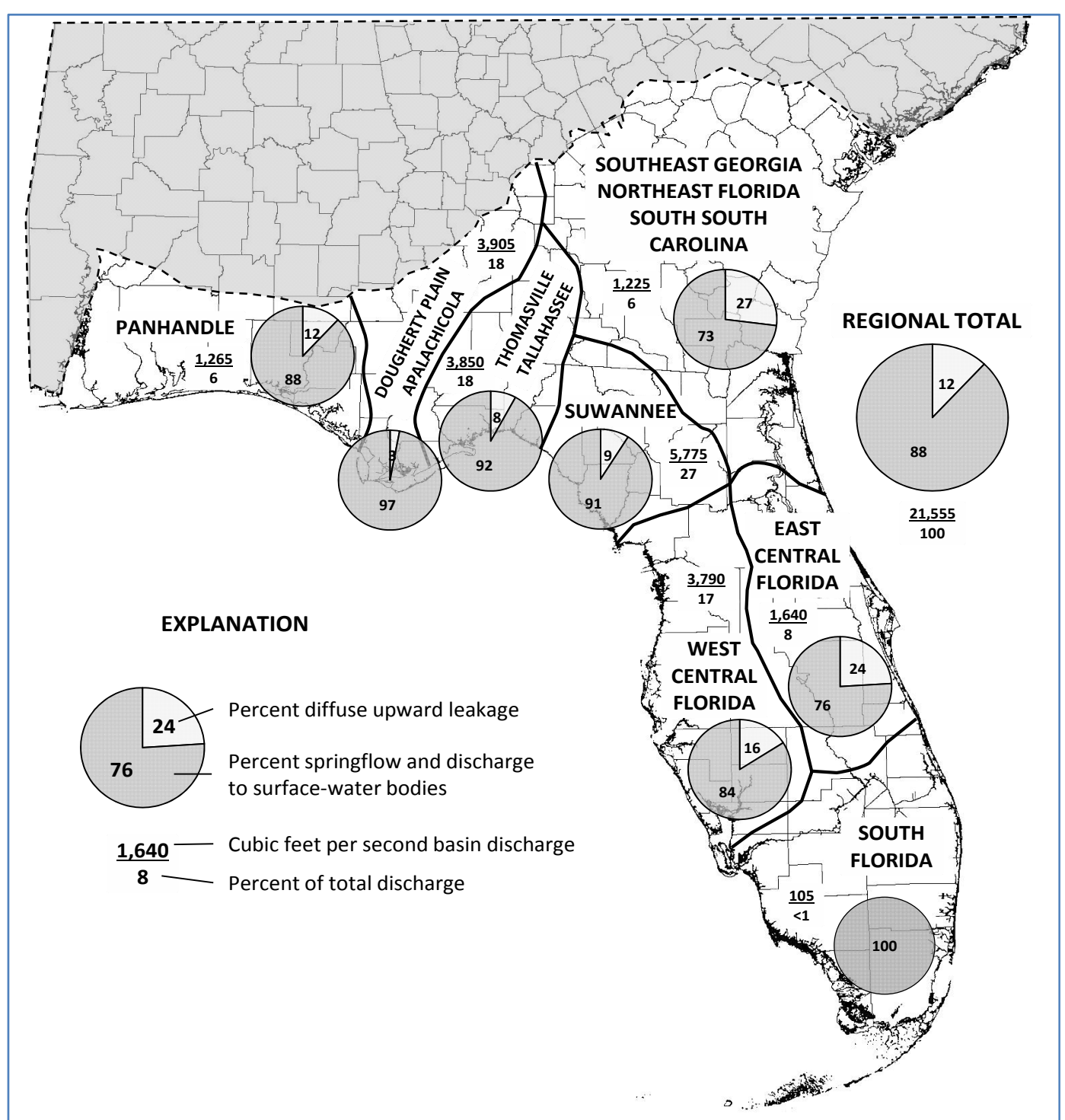

Fig. 1 Floridan Aquifer pre-development groundwater basins and model-estimated outflows (after Bush \& Johnston [1]).

and includes diffuse inputs in unconfined areas where the aquifer system is at or near land surface, as well as precipitation and surface waters that enter the aquifer system through sinkholes and swallets. Based on USGS GIS (geographic information system) files developed from Bush and Johnston [1], the fraction of the aquifer system receiving natural recharge is 64 percent of the entire surface area where the aquifer system is present. In areas where natural recharge results, the rate of natural recharge varies as a function of precipitation, the composition and thickness of the overlying sediments and soils, and the presence/absence of flowpaths through the confining layers such as solution cavities, swallets, and sinkholes. Artificial or human-induced recharge also results through gravity drainage wells, and through engineered projects designed to load stormwaters and wastewaters into the ground (i.e., rapid infiltration basins, slow-rate land application systems, retention ponds, etc.).

Prior to the installation of water-supply wells, the only appreciable groundwater discharge points from the Floridan Aquifer System were springs and permeable areas of diffuse leakage in rivers, lakes, wetlands, and estuaries [1]. The earliest water-supply wells were often free-flowing without the need for 
pumps. These "artesian" wells were essentially man-made springs, allowing pressurized groundwater to flow onto land surface from a hole drilled through the surface confining layers. Pumped wells are essentially the same as artesian or free-flowing wells with the exception that some form of energy (e.g., electricity, diesel fuel, wind power, etc.) must be used to lift the groundwater to land surface overcoming atmospheric pressure. Any pumping of groundwater reduces the groundwater level in an aquifer and reduces the flow through natural discharge points, including springs, lakes, rivers, wetlands, and other areas of diffuse leakage.

There is considerable evidence that spring flows are generally declining throughout the region supplied by the Floridan Aquifer System [3, 4]. A number of second magnitude and smaller springs have stopped flowing, either sporadically following periods of lower than average rainfall or permanently to this time primarily because of excessive groundwater pumping $[1,4]$. Historical flows have been appreciably reduced in other large, first magnitude spring systems, such as Silver, Rainbow, Wakulla, and Ichetucknee Springs, because of a combination of groundwater pumping and regional rainfall declines $[4,5]$.

Presently (2015), there has been no comprehensive attempt to use an empirically derived water budget approach to either quantify historical spring flows, to estimate groundwater availability, or to assess how rapidly spring flows are changing and the spatial distribution and extent of these spring flow reductions. An important consideration for effective groundwater management in the springs' region of Florida is to determine if human-controlled depletion of the Floridan Aquifer System is sustainable and not unacceptably affecting springs and downstream natural environments dependent upon spring flows.

This paper provides evidence that an empirical Floridan Aquifer System water budget is needed to provide more effective water-quantity management in north and central Florida. This information can be used to compare and verify water-budget results determined with the application of groundwater-flow models. Preliminary groundwater-budget estimates are presented on a regional basis for the Floridan Aquifer System in north and central Florida and for each of the four WMDs (Florida Water Management Districts) with appreciable artesian spring systems, i.e., NWFWMD (Northwest Florida), SRWMD (Suwannee River), SJRWMD (St. Johns River), and SWFWMD (Southwest Florida). No appreciable amounts of groundwater are pumped from the Floridan Aquifer System in the South Florida WMD [6] and, therefore, are not included in this water-budget analysis. Under Florida law, it is the responsibility of these WMDs to allocate surface and groundwater resources in a sustainable fashion that is not appreciably harmful to natural environmental systems dependent on adequate water flows and levels (Sections 373.042 and 373.0421, Florida Statutes). Various sources of information are used in this water-budget analysis. This analysis should be considered as a preliminary assessment of the water budgets for the four WMDs described above and the need for future assessments of the possible effects of rainfall and pumpage on spring flows. As described below, the diffuse leakage to lakes, streams, wetlands, and coastal areas is not discussed in detail.

\section{Background}

Bush and Johnston [1] used the "Floridan Aquifer Mega-Model" developed by the U.S. Geological Survey [7] to estimate the "pre-development" average groundwater discharge (diffuse upward leakage and spring flow) for eight major ground-water basins of the Upper Floridan Aquifer (Table 1). Locations of the pre-development groundwater basins are illustrated in Fig. 1. Based on the assumption that the Floridan Aquifer System storage was in approximate equilibrium during pre-development time, the estimated total average pre-development groundwater 
recharge and discharge was estimated at 21,555 cfs (cubic feet per second) or about 13,925 MGD (million gallons per day). About 19,022 cfs $(12,290$ MGD) or 88 percent of this discharge was estimated as spring flow, whereas the remainder or $2,533 \mathrm{cfs}$ (1,636 MGD) was estimated as diffuse upward leakage. Bush and Johnston [1] did not estimate the separate fractions of these Floridan Aquifer System spring flows present in Florida, Georgia, Alabama, and South Carolina, but artesian springs are known to have been present in all of these areas. However, the regional water budget prepared by Bush and Johnston [1] indicated that the majority of the spring and diffuse groundwater discharges from the Floridan Aquifer System are in Florida. This conclusion is supported by the presence of 33 recorded first magnitude springs and spring groups recorded in Florida, and none recorded in Georgia, Alabama, or South Carolina [8].

Bush and Johnston [1] also estimated the average Floridan Aquifer System groundwater recharge/discharge distribution for 1980 (Table 2).
The estimated total average groundwater discharge had increased to $24,115 \mathrm{cfs}$ or about 15,578 MGD. About 18,154 cfs (11,727 MGD) or 75 percent of this discharge was estimated as spring flow, 4,171 cfs (2,694 MGD) or 17 percent was groundwater pumpage, and the remainder or 1,790 $\mathrm{cfs}(1,156 \mathrm{MGD})$ was estimated as diffuse upward leakage. Based on regional model analysis, an average reduction of total spring and diffuse groundwater flow of about 1,611 cfs (1,041 MGD) or 7.5 percent was estimated compared to the pre-development flows. The 1980 estimated increase in recharge was about 2,560 cfs (1,654 MGD), indicating that an estimated groundwater-pumping rate from the Floridan Aquifer System of about 2,700 MGD resulted in a reduced spring and diffuse groundwater flow of about 1,000 MGD, or $37 \%$ of the pumping rate. Based on empirical and estimated pumping data, Bush and Johnston [1] concluded that groundwater pumping from the Floridan Aquifer System increased from an average of about 630 MGD in 1950 to about 3,000 MGD in 1980, an estimated 376 percent increase.

Table 1 Pre-development estimate of Floridan Aquifer System groundwater budget (cfs) by Bush and Johnston [1].

\begin{tabular}{llll}
\hline Groundwater basin & Spring flow & Diffuse leakage & Total \\
\hline Florida Panhandle & 1,113 & 152 & 1,265 \\
Dougherty Plain (GA) and Apalachicola (FL) & 3,788 & 117 & 3,905 \\
Thomasville (GA) and Tallahassee (FL) & 3,542 & 308 & 3,850 \\
Suwannee (FL) & 5,255 & 520 & 5,775 \\
Southeast GA, Northeast FL, SC & 894 & 331 & 1,225 \\
West Central FL & 3,184 & 606 & 3,790 \\
East Central FL & 1,246 & 394 & 1,640 \\
South FL & 0 & 105 & 105 \\
Total & 19,022 & 2,533 & 21,555 \\
\hline
\end{tabular}

Table 21980 estimate of Floridan Aquifer System groundwater budget (cfs) by Bush and Johnston [1].

\begin{tabular}{lllll}
\hline Groundwater basin & Spring flow & Diffuse leakage & Pumping & Total \\
\hline Florida Panhandle & 1,122 & 129 & 39 & 1,290 \\
Dougherty Plain (GA) and Apalachicola (FL) & 3,586 & 125 & 459 & 4,170 \\
Thomasville (GA) and Tallahassee (FL) & 3,432 & 312 & 156 & 3,900 \\
Suwannee (FL) & 5,002 & 518 & 230 & 5,750 \\
Southeast GA, Northeast FL, SC & 878 & 80 & 1,037 & 1,995 \\
West Central FL & 2,998 & 393 & 1,524 & 4,915 \\
East Central FL & 1,136 & 192 & 597 & 1,925 \\
South FL & 0 & 41 & 129 & 170 \\
Total & 18,154 & 1,790 & 4,171 & 24,115 \\
\hline
\end{tabular}




\section{Florida Springs Inventory}

The FDEP (Florida Department of Environmental Protection) records all reported artesian spring vents with GPS (global positioning system) coordinates. A total of 1,021 springs have been recorded in the four WMDs considered in this evaluation as of 2012. The locations of springs recorded through 2011 with county and WMD boundaries are shown in Fig. 2; the inset tables show the number of springs per WMD and the 10 counties with the highest number of recorded springs. In the future it is considered likely that additional spring vents may be identified and recorded.

There are three primary discharge mechanisms from the Floridan Aquifer System: spring flow; diffuse leakage to lakes, streams, wetlands, and coastal areas; and groundwater withdrawals. In this study, data are evaluated for spring flow and groundwater withdrawals. Limited data are available for both these flow mechanisms as subsequently discussed. It is likely that estimates of stream and river discharges include a large fraction of the diffuse leakage from the Floridan Aquifer System and that some fraction of this discharge is included in the empirical data from spring-fed rivers and streams used in this analysis. No empirical data are available for diffuse leakage from the Floridan Aquifer System resulting upstream of river and streamflow-gaging stations.

FDEP maintains a database of measured spring flows. This Florida spring flow database is redundant in that, in some cases, it includes measured flows from individual spring vents as well as from downstream stations representing multiple vents or spring groups. The FDEP spring database was manipulated for this

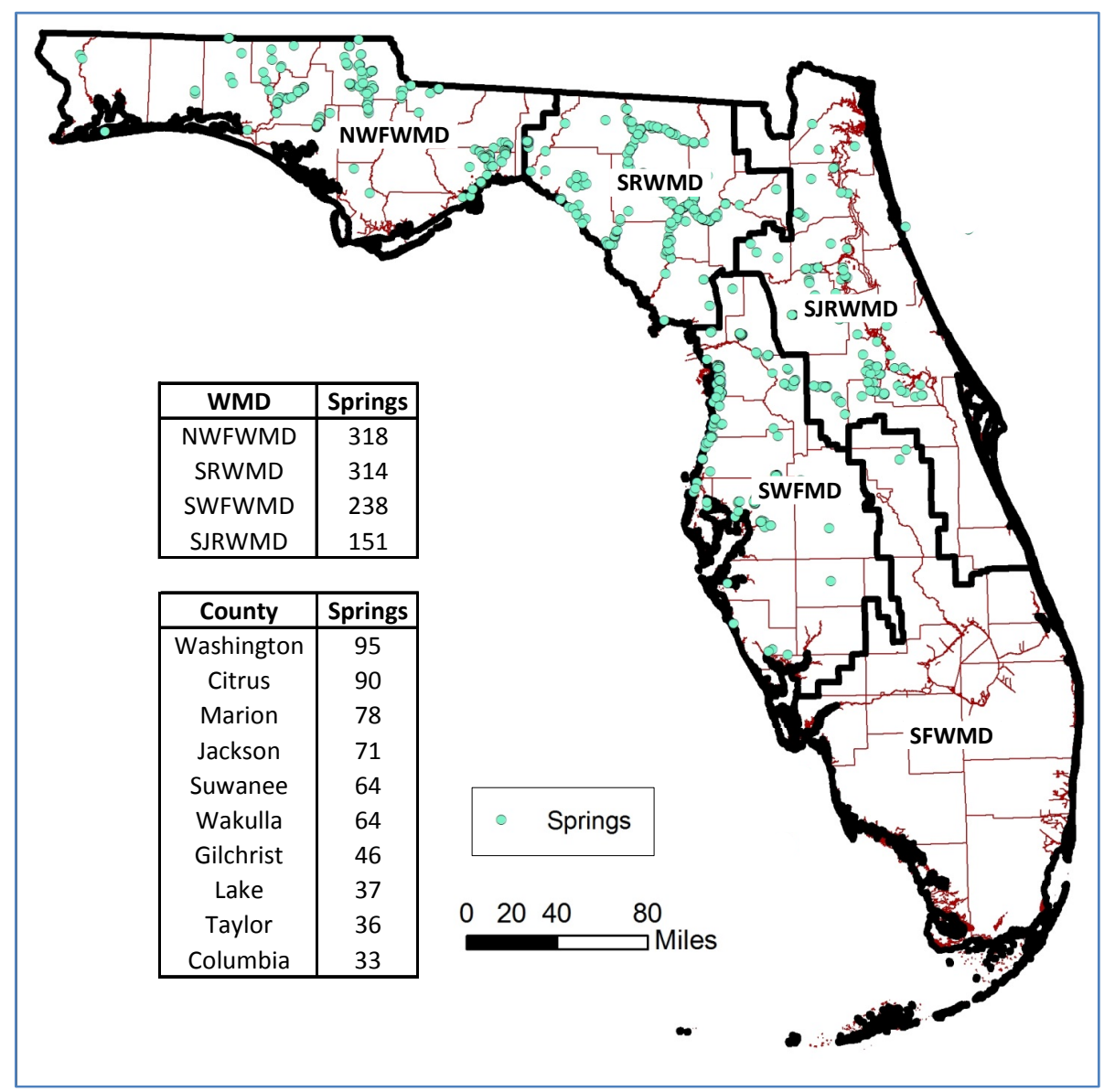

Fig. 2 Florida counties, water management districts, and FDEP 2011 springs database, including the 10 Florida counties with the highest incidence of recorded springs. 
analysis by flagging duplicate spring flow measurements and using flow data streamflow-gaging stations with the longest period-of-record. The modified spring flow database includes a total of 393 spring or spring run discharge measurement locations, including 111 stations in the NWFWMD, 124 in the SRWMD, 77 in the SJRWMD, and 81 in the SWFWMD. The two earliest spring discharge measurements in this database are from 1904 and 1907, but approximately 100 spring and spring run systems have continuous data beginning as early as the 1930s. The majority of the spring discharge data are for the period after 1960 and, specifically, from 2000 to 2009 when appreciable springs funding was made available through the Florida Springs Initiative and Task Force efforts [4].

Various simplifying assumptions were made to utilize the FDEP spring flow database to provide an empirical estimate from historical to current spring flows in Florida. The first step in this analysis summarized available spring discharge data by decade to evaluate trends for recent and historical spring flows. The beginning decade for this analysis was from 1930 through 1939, and the final decade for this analysis was from 2000 through 2009. To estimate decadal spring flow changes, only springs with data for each adjacent pair of decades were used for the analysis. Totalizing the spring flow data by decade greatly underestimates the total spring flow because of the intermittent flow record for most springs. For example, from 1980 through 1989 there are flow records from only 55 spring systems compared to the total of 393 spring systems for the period-of-record. For this reason, it was assumed that percent changes for springs with data would be approximately equal to changes for all springs in the same WMD. To develop a best estimate of current (2000-2009) spring flow, flow data for all springs in the database were estimated for the 2000s decade. For springs with no available flow data for 2000-2009, flow data for the most recent decade with a flow record were adjusted to the 2000-2009 period by use of the observed average spring flow changes for each WMD.

\section{Spring Flow Analysis}

Estimated and measured spring flows from 2000 through 2009 were summed by WMD to derive the best estimate of current average spring flow in Florida. The total measured spring flow for the 2000-2009 period using this method was $10,754 \mathrm{cfs}$ (6,950 MGD) for the 393 springs and spring groups with some available low data. This estimate does not represent the entire flow of all springs because many of the over 1,000 springs have had no recorded discharge measurements. However, generally, the springs represented in this group include all of the first, second, and third magnitude springs in Florida (i.e., springs with median flows above $1 \mathrm{cfs}$ ). Based on the assumption that the remaining 628 recorded springs in Florida each currently has an average flow of $0.5 \mathrm{cfs}$ or less (fourth magnitude), the total estimated 2000-2009 spring flow in Florida was 11,068 cfs (7,153 MGD).

When a similar calculation is completed during 1980-1989, a total flow of 16,082 cfs (10,394 MGD) was estimated for all springs in Florida. When this flow estimate is compared to the 1980 total spring and diffuse discharge estimated by Bush and Johnston [1] for the entire Floridan Aquifer System of 19,944 cfs (12,890 MGD), 81\% of total Floridan Aquifer System discharge is accounted for by the Florida spring discharge estimates. This fraction is used, in turn, to estimate a total 2000-2009 spring and diffuse groundwater flow of $13,726 \mathrm{cfs}(8,871 \mathrm{MGD})$ for the entire Floridan Aquifer System. This estimate indicates that total spring and diffuse groundwater discharge from the Floridan Aquifer System has declined by an estimated 7,829 cfs (5,060 MGD) or $36 \%$ since pre-development conditions estimated by Bush and Johnston [1]. Florida's springs contribution to the total pre-development Floridan Aquifer System groundwater discharge estimate of 21,555 cfs $(13,931$ MGD) provided by Bush and Johnston [1] was 17,381 
cfs $(11,234$ MGD) based on the 1980s $81 \%$ fraction estimated above. Thus, the pre-development to 2009 decline of Florida spring discharge was estimated at 6,313 cfs (4,080 MGD).

Estimated spring flows for the individual Florida WMDs were also made to examine the changes resulting at a regional level. Changes in measured spring flows were calculated by decade for each WMD using the same method described above for all known Florida springs. These calculations yielded the average estimated spring flow changes summarized in Table 3 and plotted in Fig. 3.

Table 3 Decadal changes in spring flow by Florida water management district.

\begin{tabular}{|c|c|c|c|c|c|c|c|c|}
\hline \multirow{3}{*}{ WMD } & \multirow{3}{*}{ Time period } & \multicolumn{4}{|c|}{ Estimated total average discharge $^{1}$} & \multirow{3}{*}{$\begin{array}{l}\text { Percent } \\
\text { change }\end{array}$} & \multirow{3}{*}{$\begin{array}{l}\text { Percent } \\
\text { cumulative } \\
\text { change }\end{array}$} & \multirow{3}{*}{$\mathrm{N}^{3}$} \\
\hline & & $\begin{array}{l}\text { Initial } \\
\text { decade }\end{array}$ & $\begin{array}{l}\begin{array}{l}\text { Final } \\
\text { decade }\end{array} \\
\end{array}$ & $\begin{array}{l}\text { Initial } \\
\text { decade }\end{array}$ & $\begin{array}{l}\begin{array}{l}\text { Final } \\
\text { decade }\end{array} \\
\end{array}$ & & & \\
\hline & & $(\mathrm{cfs})$ & $(\mathrm{cfs})$ & (mgd) & $(\mathrm{mgd})$ & & & \\
\hline \multirow{7}{*}{ NWFWMD } & $1930^{2}-1949$ & 3,709 & 3,709 & 2,397 & 2,397 & --- & --- & 3 \\
\hline & $1940-1959$ & 3,709 & 3,744 & 2,397 & 2,420 & 0.9 & 0.9 & 2 \\
\hline & $1950-1969$ & 3,744 & 4,029 & 2,420 & 2,604 & 7.6 & 8.6 & 2 \\
\hline & 1960-1979 & 4,029 & 4,336 & 2,604 & 2,802 & 7.6 & 16.9 & 5 \\
\hline & 1970-1989 & 4,336 & 3,207 & 2,802 & 2,073 & -26.0 & -13.6 & 10 \\
\hline & 1980-1999 & 3,207 & 2,989 & 2,073 & 1,932 & -6.8 & -19.4 & 3 \\
\hline & $1990-2009$ & 2,989 & 3,114 & 1,932 & 2,013 & 4.2 & -16.0 & 11 \\
\hline \multirow{7}{*}{ SJRWMD } & 1930-1949 & 1,975 & 1,997 & 1,277 & 1,290 & 1.1 & 1.1 & 11 \\
\hline & 1940-1959 & 1,997 & 1,962 & 1,290 & 1,268 & -1.7 & -0.6 & 15 \\
\hline & $1950-1969$ & 1,962 & 2,128 & 1,268 & 1,375 & 8.4 & 7.7 & 15 \\
\hline & 1960-1979 & 2,128 & 1,868 & 1,375 & 1,208 & -12.2 & -5.4 & 17 \\
\hline & 1970-1989 & 1,868 & 1,916 & 1,208 & 1,239 & 2.6 & -3.0 & 17 \\
\hline & 1980-1999 & 1,916 & 1,752 & 1,239 & 1,132 & -8.6 & -11.3 & 18 \\
\hline & 1990-2009 & 1,752 & 1,548 & 1,132 & 1,000 & -11.6 & -21.6 & 32 \\
\hline \multirow{7}{*}{ SRWMD } & 1930-1949 & 7,342 & 7,650 & 4,745 & 4,944 & 4.2 & 4.2 & 1 \\
\hline & $1940-1959$ & 7,650 & 7,539 & 4,944 & 4,872 & -1.5 & 2.7 & 1 \\
\hline & $1950-1969$ & 7,539 & 8,886 & 4,872 & 5,743 & 17.9 & 21.0 & 1 \\
\hline & 1960-1979 & 8,886 & 9,928 & 5,743 & 6,417 & 11.7 & 35.2 & 4 \\
\hline & $1970-1989$ & 9,928 & 7,691 & 6,417 & 4,971 & -22.5 & 4.8 & 7 \\
\hline & 1980-1999 & 7,691 & 4,976 & 4,971 & 3,216 & -35.3 & -32.2 & 13 \\
\hline & 1990-2009 & 4,976 & 3,789 & 3,216 & 2,449 & -23.8 & -48.4 & 51 \\
\hline \multirow{7}{*}{ SWFWMD } & 1930-1949 & 3,203 & 3,461 & 2,070 & 2,237 & 8.0 & 8.0 & 7 \\
\hline & 1940-1959 & 3,461 & 3,379 & 2,237 & 2,184 & -2.4 & 5.5 & 13 \\
\hline & 1950-1969 & 3,379 & 3,747 & 2,184 & 2,422 & 10.9 & 17.0 & 14 \\
\hline & $1960-1979$ & 3,747 & 3,048 & 2,422 & 1,970 & -18.7 & -4.9 & 22 \\
\hline & 1970-1989 & 3,048 & 3,268 & 1,970 & 2,112 & 7.2 & 2.0 & 10 \\
\hline & 1980-1999 & 3,268 & 2,969 & 2,112 & 1,919 & -9.1 & -7.3 & 8 \\
\hline & 1990-2009 & 2,969 & 2,617 & 1,919 & 1,691 & -11.9 & -18.3 & 8 \\
\hline \multirow{7}{*}{ Total } & 1930-1949 & 16,229 & 16,816 & 10,489 & 10,869 & --- & 3.6 & --- \\
\hline & 1940-1959 & 16,816 & 16,624 & 10,869 & 10,744 & --- & 2.4 & --- \\
\hline & 1950-1969 & 16,624 & 18,789 & 10,744 & 12,144 & --- & 15.8 & --- \\
\hline & $1960-1979$ & 18,789 & 19,180 & 12,144 & 12,396 & --- & 18.2 & --- \\
\hline & 1970-1989 & 19,180 & 16,082 & 12,396 & 10,394 & --- & -0.9 & --- \\
\hline & 1980-1999 & 16,082 & 12,686 & 10,394 & 8,199 & --- & -21.8 & --- \\
\hline & $1990-2009$ & 12,686 & 11,068 & 8,199 & 7,153 & --- & -31.8 & --- \\
\hline
\end{tabular}


Table 4 Decadal changes in total estimated flow in Florida's artesian springs.

\begin{tabular}{|c|c|c|c|c|c|c|c|}
\hline \multirow{3}{*}{ Time period } & \multicolumn{4}{|c|}{ Estimated total average discharge $^{1}$} & \multirow{3}{*}{$\begin{array}{l}\text { Percent } \\
\text { change }\end{array}$} & \multirow{3}{*}{$\begin{array}{l}\text { Percent } \\
\text { cumulative } \\
\text { change }\end{array}$} & \multirow{3}{*}{$\mathrm{N}^{2}$} \\
\hline & Initial decade & Final decade & Initial decade & Final decade & & & \\
\hline & $(\mathrm{cfs})$ & $(\mathrm{cfs})$ & $(\mathrm{mgd})$ & (mgd) & & & \\
\hline Predevelopment & 17,381 & & 11,234 & & --- & --- & --- \\
\hline 1930-1949 & 16,229 & 16,816 & 10,489 & 10,869 & 4 & 3.6 & 22 \\
\hline 1940-1959 & 16,816 & 16,624 & 10,869 & 10,744 & -1 & 2.4 & 31 \\
\hline 1950-1969 & 16,624 & 18,789 & 10,744 & 12,144 & 13 & 15.8 & 33 \\
\hline 1960-1979 & 18,789 & 19,180 & 12,144 & 12,396 & 2 & 18.2 & 50 \\
\hline 1970-1989 & 19,180 & 16,082 & 12,396 & 10,394 & -16 & -0.9 & 44 \\
\hline 1980-1999 & 16,082 & 12,686 & 10,394 & 8,199 & -21 & -21.8 & 43 \\
\hline 1990-2009 & 12,686 & 11,068 & 8,199 & 7,153 & -13 & -31.8 & 102 \\
\hline
\end{tabular}

Includes FDEP springs database and assigns 0.5 cfs to remaining 628 documented springs;

${ }^{2}$ Number of springs with flow data for both decades;

--- = no data or not applicable.

Estimated spring discharge changes have been variable among the WMDs. These calculations indicate that spring flows in all of the WMDs have decreased over the period-of-record with increasing reductions since 1960 to 1970 . These decreases have been particularly large in the SRWMD with three decades of greater than $20 \%$ decreases each decade. The estimated cumulative spring discharge changes for the WMDs have ranged from a $16 \%$ decrease for the NWFWMD, to a $48 \%$ decrease for the SRWMD.

The overall cumulative effect of the changes in spring flow over the period of analysis is summarized in Table 4. The estimated overall cumulative decline in spring flows in north and central Florida since the 1930 to the present is estimated at about 5,161 cfs (3,334 MGD).

\section{Groundwater Pumping}

Assessing groundwater withdrawals is a difficult process because many permitted and all un-permitted water users are not required to meter their water use. The USGS (U.S. Geological Survey) has estimated groundwater withdrawals by user type in Florida for the period from 1950 through 2010 [6]. Total groundwater withdrawals in the four WMDs of primary interest generally increased from 1950 through the 1990s. Total Florida spring discharge estimates are plotted with the estimated human groundwater withdrawals (from Marella [6], excluding the SFWMD) in Fig. 4. These data indicate a persistent decline in spring flows since 1970, during which time groundwater withdrawals from the Floridan Aquifer System in north and central Florida increased to an estimated value of $4,000 \mathrm{cfs}$ (2.6 BGD).

In 2000, the combined groundwater withdrawals from the Floridan Aquifer System in Georgia and Florida were on the order of nearly 3,640 MGD [14]. Groundwater pumping estimates are also available for southeastern Georgia for counties utilizing the Floridan Aquifer System [15]. In 2005, the estimated groundwater extraction withdrawals from the Floridan Aquifer System in Georgia totaled 658 MGD.

\section{Analysis of Rainfall Changes}

A critical part of the groundwater budget cycle is recharge from rainfall. Some recent documents have discussed that decrease in regional rainfall rate is the primary cause for decreases in spring flow statewide $[4,16,17]$. Whereas decreases in rainfall certainly affect spring flows, the primary purpose of a water-budget approach is to address the relative importance of all water flows into and out of the Floridan Aquifer System that contribute to changes in spring flow. An empirical water budget helps to identify the primary reasons for changes in and the relative magnitudes of each water input or output. 


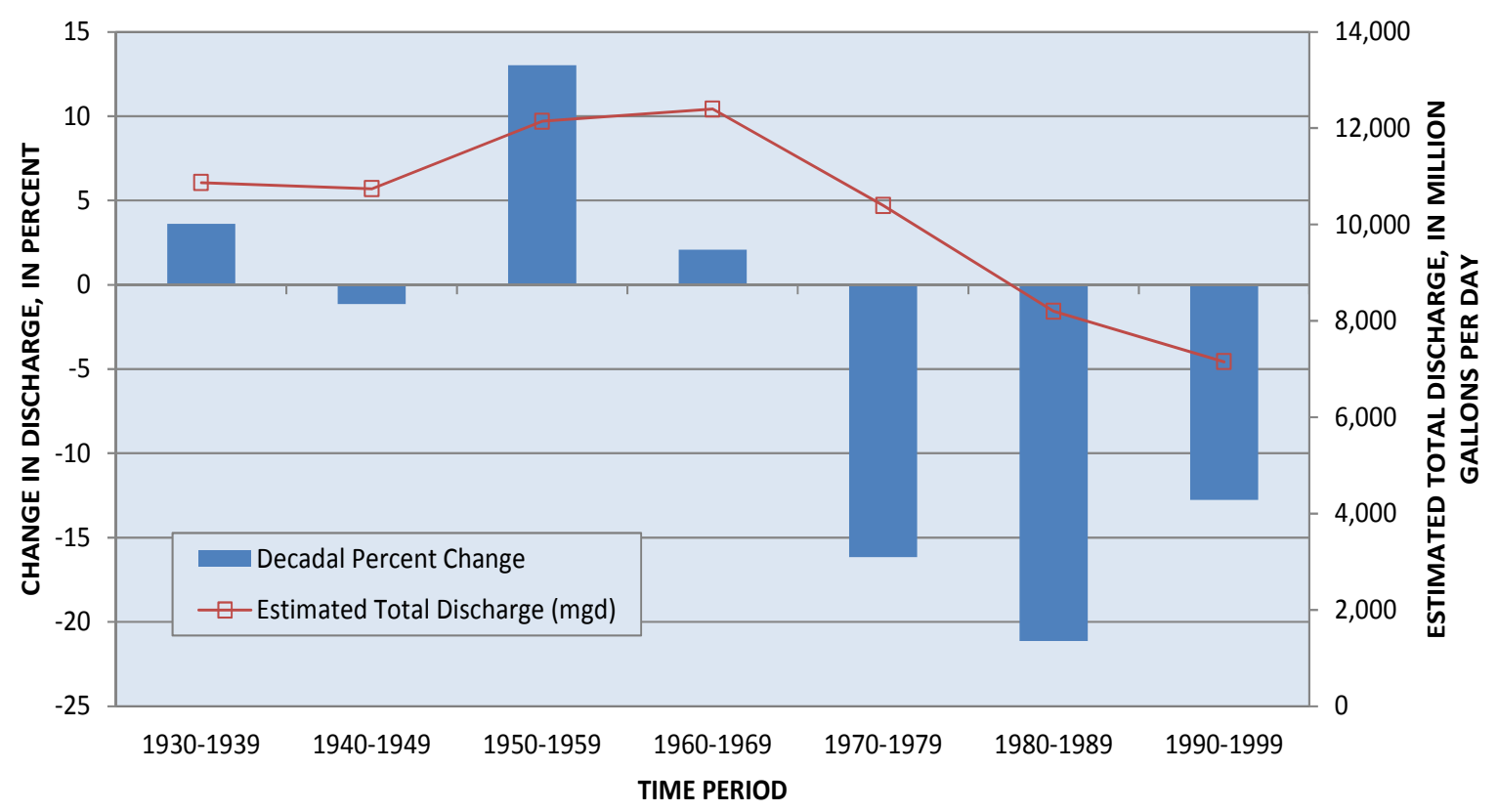

Fig. 3 Decadal changes in total estimated Florida spring flows.

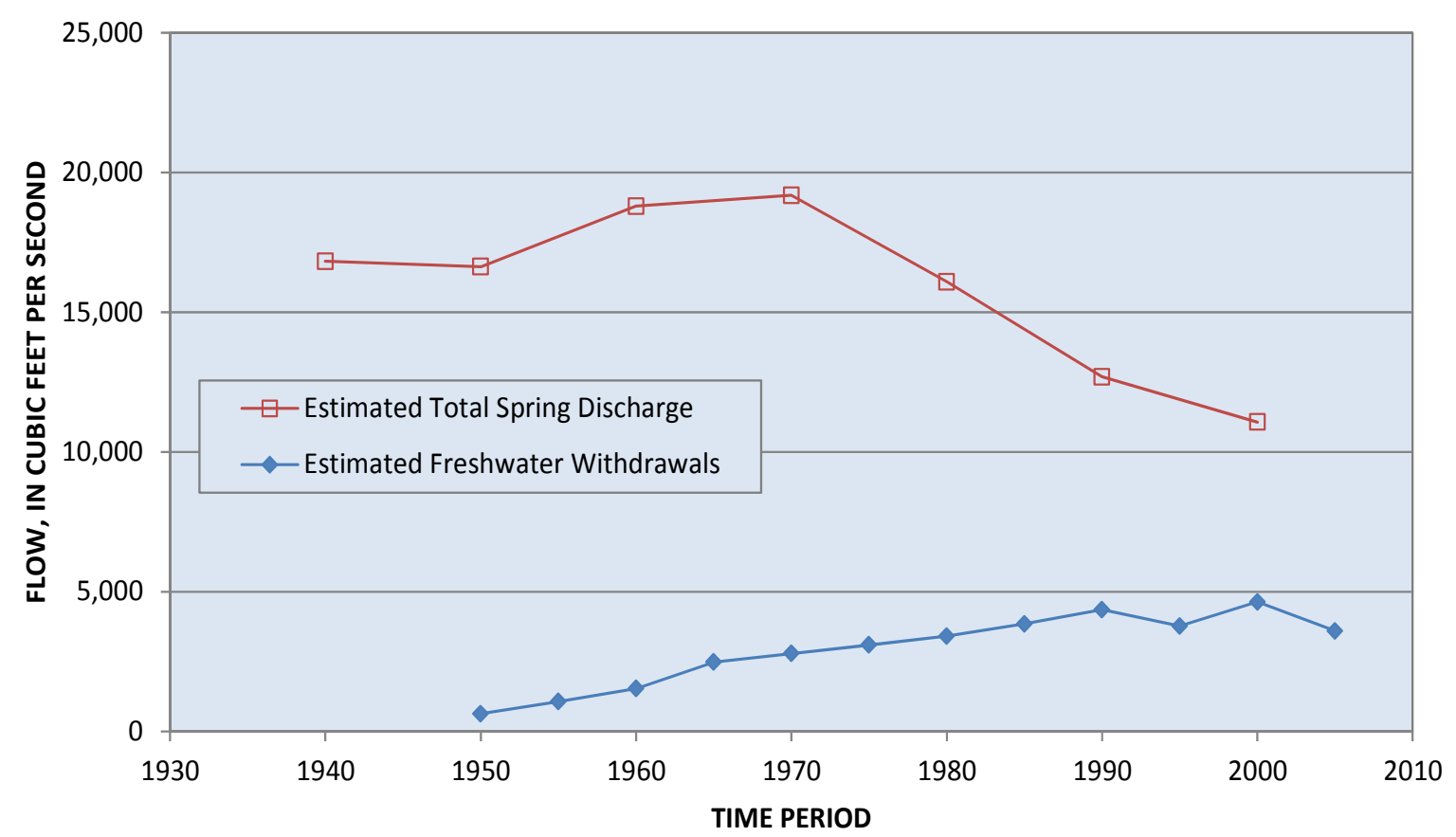

Fig. 4 Estimated flow for Florida springs, and groundwater withdrawals in the NWFWMD, SJRWMD, SRWMD, and SWFWMD [1, 9-13].

To evaluate rainfall, multiple long-term precipitation sites $[18,19]$ in each WMD were used to develop a composite average rainfall data set for each WMD. Rainfall time series were prepared for each WMD for the period from 1900 through 2010. To smooth the annual variability, the data were processed using locally weighted scatter plot smoothing [LOESS, alpha $=0.33$ ] [20]. The LOESS rainfall data are shown in Fig. 5 and 


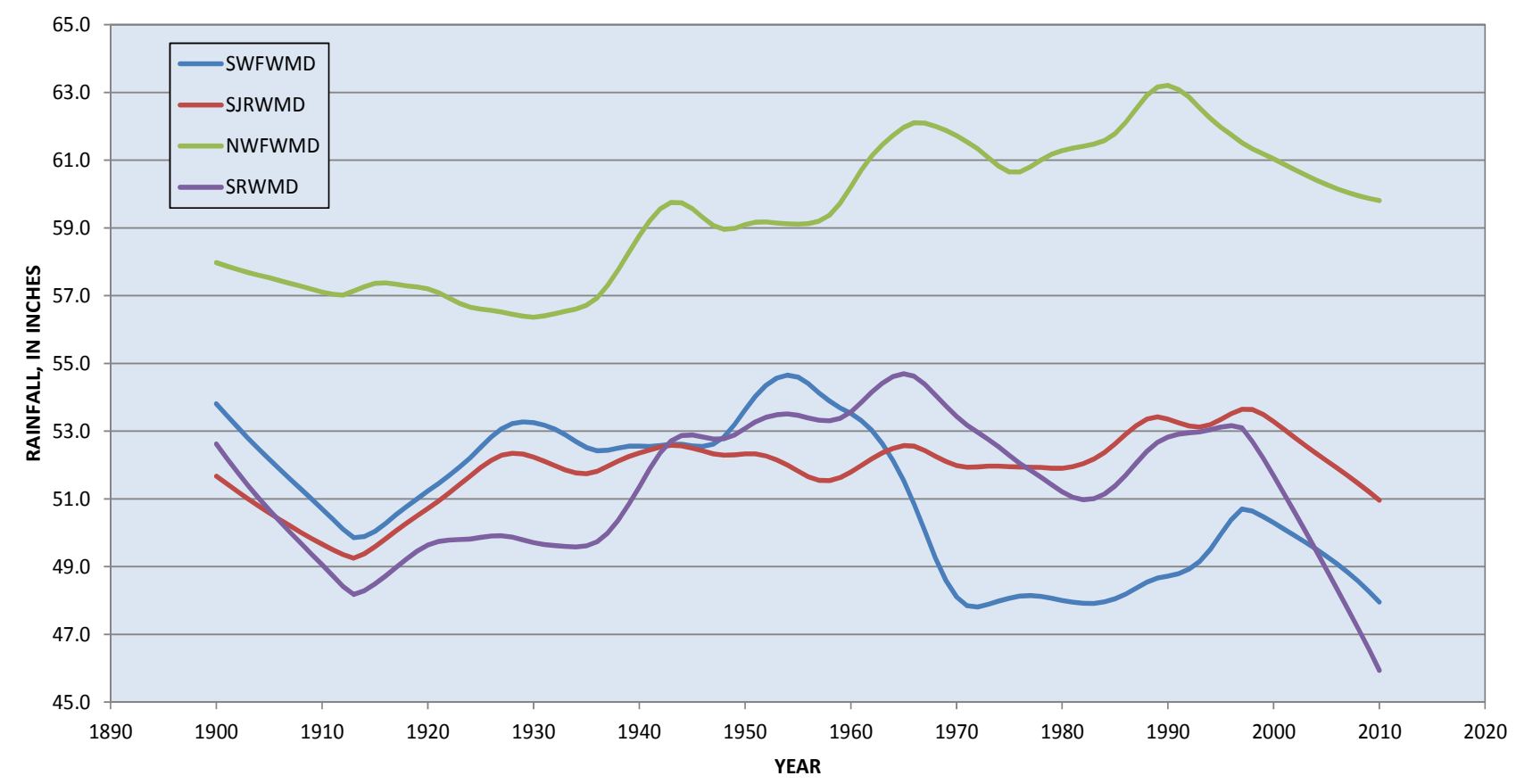

Fig. 5 LOESS rainfall by selected Florida water management district for 1900 through 2010.

show that rainfall has been relatively consistent over the past 110 years in each WMD; rainfall fluctuations generally within plus or minus $10 \%$ of the long-term average. The overall trends in rainfall amounts are positive in the NWFWMD and SJRWMD, level in the SRWMD, and slightly negative in the SWFWMD. All of the WMDs show a relatively recent decrease in rainfall beginning between 1990 and 1995, with the greatest decrease observed in the SRWMD.

\section{Relevance to Improved Groundwater Management}

A number of spring and spring run studies have been conducted by the WMDs to develop regulatory limits on human water uses $[16,17,21]$. The purpose of these studies is the determination of what flow and/or water-level reduction results in "significant harm" to the human use and water-resource values associated with the spring and spring run. Based on a variety of specific ecological indicators of harm and WMD-specific definitions of "significant harm", these studies have generally concluded that spring and spring run flows should not be reduced by human activities, on average, by more than 5 to $10 \%$ (full range from 3 to $20 \%$ ). It is apparent from the analysis of estimated spring flow changes over north and central Florida WMDs (overall average flow decline since $1930-1939$ is $32 \%$, and range from 16 to $46 \%$ by WMD) that average spring flow reductions in all four WMDs with artesian springs already approach or exceed typical WMD estimates of significant harm.

A comparison of estimated average pre-development recharge rates from Bush and Johnston [1] for north Florida, to spring flows described here, and 2010 groundwater pumping from Marella [6] is given in Table 5. These values are provided by WMD and as a total for the four WMDs that make up the north and central Florida springs' region. A number of preliminary conclusions can be made from these estimates.

Total estimated long-term average recharge of the Floridan Aquifer System in the four WMDs considered here is about 8,790 MGD compared to an estimated average total 1930-1939 spring flow of 10,498 MGD. This comparison indicates that, on average, approximately 1,708 MGD of groundwater from 
Table 5 Estimated spring/groundwater budget by Florida water management district from 1930 to 2009.

\begin{tabular}{lllllllll}
\hline WMD & \# Springs & $\begin{array}{l}\text { Est. Historic } \\
\text { Flow (MGD) }\end{array}$ & $\begin{array}{l}\text { Current Avg. } \\
\text { Flow (MGD) }\end{array}$ & $\begin{array}{l}\text { Change Flow } \\
\text { (MGD) }\end{array}$ & \% Change $\begin{array}{l}\text { Avg. Recharge } \\
\text { (MGD) }\end{array}$ & $\begin{array}{l}\text { Est. 2010 } \\
\text { Pumping (MGD) }\end{array}$ & $\begin{array}{l}\text { Pumping as \% } \\
\text { Recharge }\end{array}$ \\
\hline NWF & 318 & 2,397 & 2,013 & -385 & -16 & 2,299 & 253 & 11 \\
SJR & 151 & 1,277 & 1,000 & -276 & -22 & 1,530 & 979 & 64 \\
SR & 314 & 4,745 & 2,449 & $-2,296$ & -48 & 3,067 & 219 & 7 \\
SWF & 238 & 2,070 & 1,691 & -379 & -18 & 1,893 & 965 & 51 \\
Total & 1,021 & 10,489 & 7,153 & $-3,336$ & -32 & 8,790 & 2,416 & 27 \\
\hline
\end{tabular}

outside of Florida historically was part of Florida's spring flows. Recharge to the Floridan Aquifer System in the Coastal Plains of Georgia and Alabama constitutes some of the groundwater flow to Florida springs. In Florida, there is a requirement for the WMDs to use "local sources first". The estimates in Table 5 indicate that a large quantity of groundwater is moving through the natural "plumbing" of the Floridan Aquifer System among the various WMDs as has been previously concluded by the U.S. Geological Survey [22]. For example, 2010 groundwater pumping in the SRWMD was estimated by the USGS as about 219 MGD or about $7 \%$ of the estimated average recharge to the Floridan Aquifer System in the WMD. In spite of the estimated local recharge contribution to the aquifer system, spring flows in the SRWMD have declined by an estimated 2,296 MGD since pre-development, or a total of $48 \%$.

The SJRWMD had an estimated 2010 groundwater withdrawal of 979 MGD or about $64 \%$ of the estimated recharge to the Floridan Aquifer System in the area. Spring flows within the SJRWMD have only declined by an estimated 276 MGD or $22 \%$. Comparing withdrawals and spring flows between the SRWMD and SJRWMD provides additional evidence of the regional effects of groundwater pumping on Floridan Aquifer System water levels and spring flows. Relatively less developed areas, such as those within the SRWMD, with high recharge rates and relatively low groundwater withdrawals have relatively large reductions in spring flows resulting from large withdrawals in adjacent more developed areas in Florida with relatively low natural recharge rates.
Of the four WMDs containing artesian springs, much greater groundwater withdrawals are present in the SJRWMD and SWFWMD than can be satisfied with natural recharge in order to maintain sustainable spring flows. Not all consumptive or non-consumptive groundwater pumpage appreciably affects spring flows in the WMDs. If groundwater flow could be restricted within WMDs with no flows across WMD boundaries, it is hypothesized that local spring flows in the SJRWMD and SWFWMD could be reduced by more than one-half of their average historical values.

The information and results presented here are reasons for concern about the sustainability of current groundwater withdrawals from the Floridan Aquifer System in north and central Florida. If it is assumed that springs are "significantly harmed" with a 5 to $10 \%$ reduction in long-term average flow from consumptive groundwater pumpage, this analysis indicates that the state's total net utilization of groundwater (the difference between total pumped and induced recharge), that would protect from 90 to $95 \%$ of average historical spring flows is in the range of 500 to 1,000 MGD. As summarized in this paper, the USGS has estimated that average groundwater pumping from the Floridan Aquifer System in 2000 was about 3,640 MGD, with 2,416 MGD in Florida (2010), and 658 MGD in Georgia (2005). Assuming a relatively large percentage (for example, $40 \%$ ) of Florida's portion of this pumped groundwater is recharged, results in an estimated net groundwater use of about 1,450 MGD or from about 450 to 950 MGD more than is safe to maintain springs that are "not 
significantly harmed". A review of present Florida groundwater consumptive use permits indicates that the total allocated groundwater use in all of the permits in these four WMDs total about 4,600 MGD (the actual consumptive uses usually are less than the permitted quantities) or about 3,600 to 4,100 MGD more than the assumed flow reductions that result in significant harm to the springs.

\section{Conclusions and Recommendations}

The effects of human water-management activities and especially groundwater pumping from the Floridan Aquifer System on observed spring flow reductions is an important issue in the water resources in Florida. WMD groundwater modeling provides mixed results concerning the apparent effects of groundwater pumping on spring flows. For example, although the long-term average flow at Silver Springs since pre-development has declined by $32 \%$, only $5 \%$ is attributed to the effects of groundwater pumping according to groundwater modeling performed by the SJRWMD [21]. A long-term average flow reduction of $25 \%$ at Rainbow Springs in the SWFWMD is evident in the historical data, although groundwater modeling performed by the SWFWMD indicates that only $1 \%$ of this reduction can be attributed to groundwater pumpage (SWFWMD, Ron Basso, personal communication, August 31, 2012). Similar results are indicated for groundwater modeling performed by the SRWMD. In this case, observed flow reductions since pre-development in the Santa $\mathrm{Fe}$ and Suwannee Rivers are approximately 40\%, whereas SRWMD modeling results indicate that only $1 \%$ of the flow reductions are attributed to groundwater pumpage.

Examination of the long-term rainfall trends summarized in Fig. 4 above, as well as the comparison between estimated groundwater recharge and pumping listed in Table 5, indicates possible problems concerning the accuracy and precision of these groundwater models in simulating reductions of spring flow resulting from groundwater pumping. An independent and empirical water-budget approach, as well as other approaches and methods, should be used to assess the accuracy and precision of groundwater model simulations and predictions that are used on a daily basis to allocate present groundwater-resources and future water-resources planning by the WMDs.

A water-budget approach can be utilized for assessing present water-resource conditions and possible future development. This study does not attempt to produce a complete water budget, but is focused on describing the need to incorporate this approach in the management of Florida's groundwater supplies and the review and issuance of consumptive use permits. It is recommended that all of the WMDs be required to estimate empirical water budgets at a frequency of each 3 to 5 years, utilizing state-of-the-art tools for estimating rainfall, evapotranspiration losses, recharge, groundwater pumping, spring flows, and groundwater storage in the Floridan Aquifer System.

A portion of the rainfall data needed for a full water-budget approach for estimating water availability are currently available, although the quality and quantity of the data are highly variable both spatially and historically. Currently, multiple organizations maintain weather stations that report rainfall and evapotranspiration throughout the state. Groundwater pumping data are needed for developing an accurate water budget. It is critical that groundwater pumping data be collected on a systematic basis from the Floridan Aquifer System. The WMDs and other agencies need to improve the collection and analysis of groundwater pumping data to accomplish this task. A more extensive groundwater-level network for measuring water levels on a systematic basis is needed for developing accurate water budgets. Additional comparisons of results from water-budget methods and groundwater-flow modeling are needed to evaluate the 
effects of pumpage, rainfall, and other factors on the hydrology and, specifically, spring flow, in Florida.

Ultimately, the most important responsibility of any water manager is a quantitative understanding of the resource that is being managed. There is a lack of information concerning the safe yield of the Floridan Aquifer System in the WMD areas. The water-budget estimates described in this report vary appreciably from water-budget estimates computed with use of groundwater-flow models. It is imperative that a more reliable and accurate method be developed to estimate the capacity of the Floridan Aquifer System to provide ample water for human consumption and the natural environment.

\section{References}

[1] Bush, P. W., and Johnston, R. H. 1988. Ground-Water Hydraulics, Regional Flow, and Ground-Water Development of the Floridan Aquifer System in Florida and in Parts of Georgia, South Carolina, and Alabama. Reston: Unites States Geological Survey.

[2] Spechler, R. M. 2001. "The Relation between Structure and Saltwater Intrusion in the Floridan Aquifer System, Northeastern Florida." In U.S. Geological Survey Karst Interest Group Proceedings, edited by Kuniansky E. L. Water Resources Investigation Report 01-4011, 25-9.

[3] Copeland, R., Doran, N. A., White, A. J., and Upchurch, S. B. 2009. Regional and Statewide Trends in Florida's Spring and Well Groundwater Quality (1991-2003). Bulletin No. 69, Florida Geological Survey, Tallahassee, FL.

[4] Harrington et al. 2010. Florida Springs Initiative Monitoring Network Report and Recognized Sources of Nitrate. Tallahassee, F.L.: Florida Department of Environmental Protection.

[5] Grubbs, J. W., and Crandall, C. A. 2007. "Exchanges of Water between the Upper Floridan Aquifer and the Lower Suwannee and Lower Santa Fe Rivers, Florida." U.S. Geological Survey Professional Paper 1656-C, 83.

[6] Marella, R. L. 2013. Water-Use Data Tables, 2010. United States Geological Survey. Retrieved October 30, 2013, from

http://fl.water.usgs.gov/infodata/wateruse/datatables 2010 . html.

[7] Sepulveda, N. 2002. Simulation of Ground-Water Flow in the Intermediate and Floridan Aquifer Systems in Peninsular Florida. Water-Resources Investigations Report 2002-4009.
[8] Meinzer, O. E. 1927. "Large Springs in the United States." U.S. Geological Survey Water Supply Paper 557.

[9] Marella, R. L. 1988. Water Withdrawals, Use, and Trends in Florida, 1985. WRIR 88-4103. Retrieved January 27, 2014, from http://sofia.usgs.gov/publications/wri/88-4103/.

[10] Marella, R. L. 1992. Water Withdrawals, Use, and Trends in Florida, 1990. WRIR 92-4140. Retrieved January 27, 2014, from http://pubs.er.usgs.gov/publication/wri924140.

[11] Marella, R. L. 1999. Water Withdrawals, Use, Discharge, and Trends in Florida, 1995. WRIR 99-4002. Retrieved January 27, 2014, from http://fl.water.usgs.gov/Abstracts/wri99_4002_marella.ht $\mathrm{ml}$.

[12] Marella, R. L. 2004. Water Withdrawals, Use, Discharge, and Trends in Florida, 2000. SIR 2004-5151. Retrieved January 27, 2014, from http://pubs.usgs.gov/sir/2004/5151/.

[13] Marella, R. L. 2009. Water Withdrawals, Use, and Trends in Florida, 2005. U.S. Geological Survey Scientific Investigations Report 2009-5125, SIR 2009-5125. Retrieved January 27, 2014, from http://pubs.usgs.gov/sir/2009/5125/.

[14] Williams, L. J., Dausman, A. D., and Bellino, J. C. 2011. "Relation of aquifer confinement and Long-Term Groundwater-Level Decline in the Floridan Aquifer System." Power Point Presentation. U.S. Geological Survey.

ftp://ftp.sjrwmd.com/SRWMD-SJRWMD_Regional_Dra wdown_Documents/REF\%2062_Williams_NGWA_Rela tionOfGWLevDeclineToConfinement.pdf.

[15] Fanning, J. L., and Trent, V. P. 2009. Water Use in Georgia by County for 2005; and Water-Use Trends, 1980-2005. Scientific Investigations Report 2009-5002, U.S. Geological Survey, Washington, D.C.

[16] Heyl, M. G., Leeper, D., Basso, R., and Kelly, M. 2012. Recommended Minimum Flows for the Chassahowitzka River System. Brooksville, F.L.: Southwest Florida Water Management District.

[17] Suwannee River Water Management District (SRWMD). 2013. Minimum Flows and Levels for the Lower Santa Fe and Ichetucknee Rivers and Priority Springs. Final Report, November 22, 2013. Live Oak, Florida.

[18] Howard, T. Odum Florida Springs Institute. 2012. "Santa Fe Springs Restoration Plan." Paper prepared for the Santa Fe River Basin Springs Working Group.

[19] Winsburg, M. D. 2013. "Long-Term Precipitation Data." Long-Term Precipitation Data, Florida Climate Center, from Florida State University. Retrieved January 13, 2014, $\mathrm{http}: / /$ climatecenter.fsu. edu/products-services/data.

[20] Cleveland, W. S., and Devlin, S. J. 1988. "Locally 
Weighted Regression: An Approach to Regression Analysis by Local Fitting." Journal of the American Statistical Association 83: 596-610.

[21] Hall, G. B., and Slater, J. B. 2013. Minimum Flows and Levels Determination: Silver Springs and Silver River, Marion County, Florida. Palatka, FL.: Draft Technical
Publication.

[22] Grubbs, J. W. 2011. "Analysis of Long-Term Trends in Flow from a Large Spring Complex in Northern Florida." In U.S. Geological Survey Karst Interest Group Proceedings, edited by Kuniansky, E. L. Fayetteville, Arkansas, p. 160-7. 